\title{
Effects of various inhibitory substances and immobilization on ethanol production efficiency of a thermotolerant Pichia kudriavzevii
}

\author{
Ifeanyi A. Ndubuisi ${ }^{1,2,4 \dagger}$, Qijian Qin 1,3†, Guiyan Liao33, Bin Wang ${ }^{3}$, Anene N. Moneke4, James C. Ogbonna ${ }^{4}$, \\ Cheng $\operatorname{Jin}^{1,2^{*}}$ and Wenxia Fang ${ }^{1,3^{*}}$ (D)
}

\begin{abstract}
Background: Although bioethanol production has been gaining worldwide attention as an alternative to fossil fuel, ethanol productivities and yields are still limited due to the susceptibility of fermentation microorganisms to various stress and inhibitory substances. There is therefore an unmet need to search for multi-stress-tolerant organisms to improve ethanol productivity and reduce production cost, particularly when lignocellulosic hydrolysates are used as the feedstock.
\end{abstract}

Results: Here, we have characterized a previously isolated Pichia kudriavzevii LC375240 strain which is thermotolerant to high temperatures of $37^{\circ} \mathrm{C}$ and $42^{\circ} \mathrm{C}$. More excitingly, growth and ethanol productivity of this strain exhibit strong tolerance to multiple stresses such as acetic acid, furfural, formic acid, $\mathrm{H}_{2} \mathrm{O}_{2}$ and high concentration of ethanol at $42^{\circ} \mathrm{C}$. In addition, simple immobilization of LC375240 on corncobs resulted to a more stable and higher efficient ethanol production for successive four cycles of repeated batch fermentation at $42^{\circ} \mathrm{C}$.

Conclusion: The feature of being thermotolerant and multi-stress-tolerant is unique to P. kudriavzevii LC375240 and makes it a good candidate for second-generation bioethanol fermentation as well as for investigating the molecular basis underlying the robust stress tolerance. Immobilization of P. kudriavzevii LC375240 on corncobs is another option for cheap and high ethanol productivity.

Keywords: Bioethanol production, Pichia kudriavzevii, Thermotolerant, Immobilization, Multi-stress tolerance, Batch fermentation

\section{Background}

Second-generation bioethanol has been gaining worldwide attention as an alternative to fossil fuel due to the advantages of being sustainable, renewable and environmentally friendly. However, the commercialization of bioethanol is still limited by the high cost of production. Therefore, cheap and abundant non-edible feedstock

\footnotetext{
*Correspondence: jinc@im.ac.cn; wfang@gxas.cn

${ }^{\dagger}$ Ifeanyi A. Ndubuisi and Qijian Qin contributed equally to this work

${ }^{1}$ National Engineering Research Center for Non-Food Biorefinery, Guangxi Academy of Sciences, Nanning, China

Full list of author information is available at the end of the article
}

from agricultural and forestry biomass, such as lignocellulosic materials of agricultural residues, food and industrial waste, are currently being investigated for large-scale production of bioethanol [1]. The bioconversion of lignocellulosic biomass to ethanol involves three major steps: pretreatment, saccharification and fermentation. Pretreatment disrupts recalcitrant structures of lignocellulosic materials to make the cellulose and hemicellulose more accessible to saccharification enzymes, thus improving the digestibility of carbohydrate polymers into fermentable sugars [2]. In the saccharification step, cell wall degrading enzymes such as cellulases, cellobiases and $\beta$-glucosidases are used to hydrolyse pretreated

c) The Author(s) 2020. This article is licensed under a Creative Commons Attribution 4.0 International License, which permits use, sharing, adaptation, distribution and reproduction in any medium or format, as long as you give appropriate credit to the original author(s) and the source, provide a link to the Creative Commons licence, and indicate if changes were made. The images or other third party material in this article are included in the article's Creative Commons licence, unless indicated otherwise in a credit line to the material. If material is not included in the article's Creative Commons licence and your intended use is not permitted by statutory regulation or exceeds the permitted use, you will need to obtain permission directly from the copyright holder. To view a copy of this licence, visit http://creativeco mmons.org/licenses/by/4.0/. The Creative Commons Public Domain Dedication waiver (http://creativecommons.org/publicdomain/ zero/1.0/) applies to the data made available in this article, unless otherwise stated in a credit line to the data. 
lignocellulosic materials into five or six carbon sugars. Fermentation is the last step where the sugars produced from the saccharification step are converted to bioethanol by fermentation microorganisms. Simultaneous saccharification and fermentation (SSF) is usually preferred for bioethanol production based on the advantages of combining enzymatic hydrolysis and fermentation in a single fermenter, simpler operation, less cost and shorter completion time. However, the drawback is the different temperature requirement between saccharification and fermentation, as high temperature is usually required for the hydrolysis step, whereas most fermentation organisms are inhibited at high temperatures. Using thermotolerant microorganisms for ethanol production provides solution to this limitation and a great strategy for reducing the cooling and sterilization cost, as well as lower the risk of bacterial contamination during SSF.

Multiple substances, such as furfural, acetic acids and formic acids that are inhibitory to the fermentation process are released during the thermo-chemical pretreatment of the biomass. Furfural and its derivatives have been shown to reduce the organism growth rate, ATP yield and ethanol production significantly [3]. Acetic and formic acids could enter the cell in associated forms, but are dissociated inside the cell leading to a decrease in intracellular $\mathrm{pH}$ as well as a reduction in biomass yield and availability [4]. Oxygen radicals such as $\mathrm{H}_{2} \mathrm{O}_{2}$ are a result of the microbial response to stressful conditions, and are harmful to cell viability and proliferation [5]. In addition, high concentrations of the produced ethanol is also inhibitory to the fermentation microorganisms by impairing cellular wall permeability, disrupting sorting and signaling functions, as well as reducing metabolic activity, thus causing a delay in cell cycle [4]. These multi-stress conditions have made commercial ethanol production from lignocellulosic biomass more challenging. Consequently, multi-stress-tolerant organisms are necessary to increase ethanol production and yield, and to reduce the production cost.

Immobilization of fermentation organisms is a strategy to improve ethanol production by entrapping the fermentation organism in adhesible surfaces or compartments. When compared to free cells, immobilized cells have many advantages including ease of biomass separation from fermentation medium at the end of production, reducing contamination risk, enhancing cell stability and viability over several operational cycles, protection of cells from inhibitory compounds, faster production and overall cost savings. Immobilization of Saccharomyces cerevisiae cells for bioethanol production as well as production of other bio-products has been studied extensively [6, 7]. Immobilization by adsorption of cells on solid materials or entrapment of cells in a matrix such as calcium-alginate beads and K-carrageenan for bioethanol production has been utilized and shown to be cheap, non-toxic to the cells and easily achievable [8-10]. Lignocellulosic materials, such as loofa sponge (Luffa cylindrica), corncob, sugarcane bagasse and coconut bract, have advantages of cost reduction, ease of immobilization, availability, reusability, higher stability and durability when compared to entrapment beads. These materials have been widely utilized for immobilization [11-14]. $S$. cerevisiae is the most widely studied and applied microorganism for ethanol production due to its robustness and other good physiological characteristics when compared to filamentous fungi, bacteria and other yeasts [15, 16]. Despite possessing the above advantages, most S. cerevisiae cannot be used effectively for ethanol production using SSF method as its activity is inhibited at a temperature above $40{ }^{\circ} \mathrm{C}$. Yeast species such as Kluyveromyces marxianus, few S. cerevisiae and Pichia kudriavzevii that are capable of producing ethanol between 40 and $45{ }^{\circ} \mathrm{C}$ have been reported [17-20]. P. kudriavzevii is exceptionally stress tolerant and has a growing role in bioethanol production [21] and several P. kudriavzevii strains have been reported to grow and produce ethanol effectively at high temperatures [19, 22-24]. However, only a few strains of $P$. kudriavzevii $[25,26]$ have been studied for ethanol production under multiple stress conditions.

In our previous study, we isolated a $P$. kudriavzevii LC375240 strain that could grow and produce ethanol within a temperature range of $30{ }^{\circ} \mathrm{C}$ to $42{ }^{\circ} \mathrm{C}$, and within a $\mathrm{pH}$ of 3 to 8 [27]. In this study, we expand upon previous work and demonstrated that $P$. kudriavzevii LC375240 is resistant to various inhibitory substances. Simple immobilization on lignocellulosic waste such as corncobs enables this thermotolerant and multi-stress-tolerant $P$. kudriavzevii strain to be stable for repeated batch production of bioethanol.

\section{Results}

Thermotolerant Pichia kudriavzevii produces high amount of bioethanol

Although the thermotolerance feature of $P$. kudriavzevii LC375240 has been reported previously [27], the growth rate and plate spot assay have not been tested yet. Here, the growth kinetics was continuously measured in YPD broth medium at $30{ }^{\circ} \mathrm{C}, 37{ }^{\circ} \mathrm{C}$ and $42{ }^{\circ} \mathrm{C}$. As shown in Fig. 1a, growth of $P$. kudriavzevii LC375240 at the initial $7.5 \mathrm{~h}$ was nearly the same between 30 and $37^{\circ} \mathrm{C}$, and the absorbance at $30{ }^{\circ} \mathrm{C}$ became higher and reached the stationary phase at $10 \mathrm{~h}$, whereas the growth at $37{ }^{\circ} \mathrm{C}$ reached the stationary phase at $9 \mathrm{~h}$ with 0.14 lower $\mathrm{OD}_{600}$ than that at $30{ }^{\circ} \mathrm{C}$. The growth rate at $42{ }^{\circ} \mathrm{C}$ was obviously lower before $18 \mathrm{~h}$, but reached the stationary phase with nearly the same absorbance as that of $37^{\circ} \mathrm{C}$. When the 


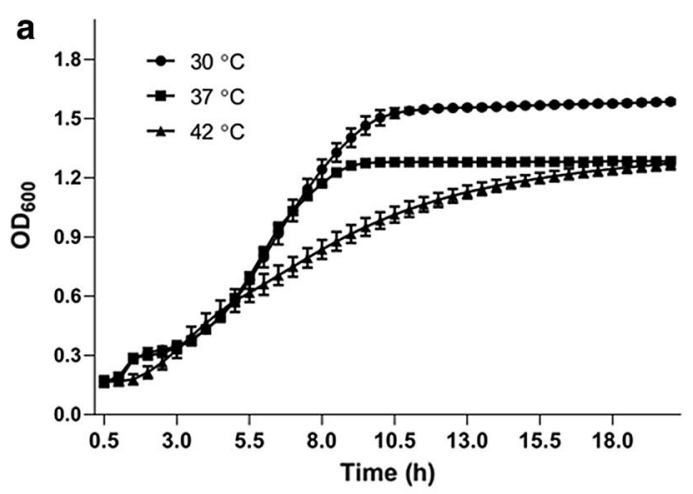

b
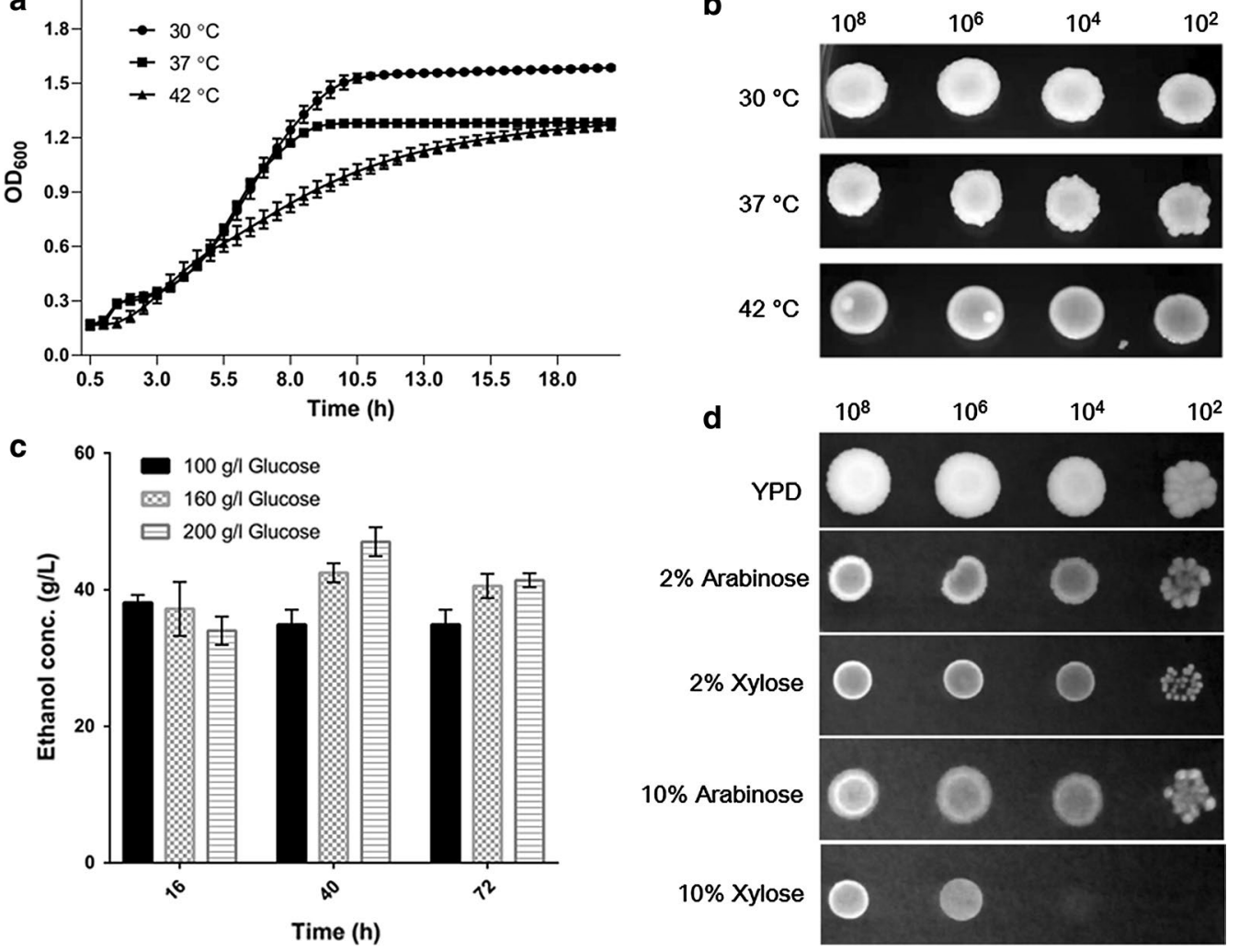

Fig. 1 Growth of thermotolerant P. kudriavzevii LC375240 and ethanol production. a Kinetic growth curves of P. kudriavzevii LC375240 in YPD broth were monitored every $0.5 \mathrm{~h}$ interval for $20 \mathrm{~h}$ using plate reader for the indicated temperatures. $\mathbf{b}$ The indicated cell numbers were inoculated on YPD plates and incubated at $30^{\circ} \mathrm{C}, 37^{\circ} \mathrm{C}$ and $42^{\circ} \mathrm{C}$ for $24 \mathrm{~h}$. c Ethanol productions from YPD media with $100 \mathrm{~g} / \mathrm{l}, 160 \mathrm{~g} / \mathrm{l}, 200 \mathrm{~g} / \mathrm{l}$ glucose were determined after $16 \mathrm{~h}, 40 \mathrm{~h}$ and $72 \mathrm{~h}$ fermentation at $42^{\circ} \mathrm{C}$. $\mathbf{d}$ The indicated cell numbers were inoculated on YPD plates or plates with two pentose sugars as sole carbon sources and incubated at $42^{\circ} \mathrm{C}$ for $48 \mathrm{~h}$

spot assay on YPD plates was checked after $48 \mathrm{~h}$ incubation, there were no differences between the three tested temperatures even at low inoculum (Fig. 1b). It is clear that the P. kudriavzevii LC375240 is thermotolerant and capable of growing at $42^{\circ} \mathrm{C}$.

Bioethanol productivity is highly dependent on the concentration of the carbon sources. The ethanol production from $100 \mathrm{~g} / \mathrm{l}$ glucose reached a peak value of $38.1 \mathrm{~g} / \mathrm{l}$ at $16 \mathrm{~h}$, and a stably retained value of $34.9 \mathrm{~g} / \mathrm{l}$ at $40 \mathrm{~h}$ and $72 \mathrm{~h}$ (Table 1). The maximum ethanol concentrations of $42.5 \mathrm{~g} / \mathrm{l}$ and $47.1 \mathrm{~g} / \mathrm{l}$ at $40 \mathrm{~h}$ were obtained from glucose concentrations of $160 \mathrm{~g} / \mathrm{l}$ and $200 \mathrm{~g} / \mathrm{l}$, respectively (Fig. 1c and Table 1). However, when fermentation was prolonged to $72 \mathrm{~h}$ the ethanol concentration produced from $160 \mathrm{~g} / \mathrm{l}$ and $200 \mathrm{~g} / \mathrm{l}$ glucose decreased (Fig. 1c), probably due to ethanol consumption by the yeast cells when glucose was depleted at the late stage. It is important to note that the ethanol yield decreased when the initial concentration of glucose increased (Table 1).

When lignocellulosic hydrolysates are used as feedstock, high amount of pentose sugars such as D-xylose or L-arabinose are released from hemicellulose [28]. When we used those two pentose sugars as sole carbon sources our P. kudriavzevii LC375240 strain could grow, but at a slower rate than in glucose medium at both $37{ }^{\circ} \mathrm{C}$ and $42{ }^{\circ} \mathrm{C}$ (Fig. 1d). Particularly, growth on $10 \%$ xylose is severely restricted compared to $10 \%$ arabinose plates. Moreover, nearly no ethanol was produced from the pentose media due to the limited growth, suggesting that our P. kudriavzevii strain could assimilate pentose sugars for growth, but could not ferment them to produce ethanol.

\section{Stress tolerance of $P$. kudriavzevii LC375240 to furfural and formic acid}

During the pretreatment and saccharification steps of lignocellulosic materials many by-products such as acetic acid, furfural and formic acid are released. These compounds inhibit the growth of fermentation microorganisms and thus reduce the bioethanol production. In our previous study, the LC375240 strain exhibited high tolerance to $70 \mathrm{mM}$ acetic acid [27], implying it is a stress-tolerant strain. In order to know whether it is 
Table 1 Kinetic parameters of ethanol production with different concentrations of glucose at $42{ }^{\circ} \mathrm{C}$

\begin{tabular}{lllll}
\hline Glucose concentration $(\mathbf{g} / \mathbf{l})$ & Time $(\mathbf{h})$ & Ethanol concentration $\mathbf{g} / \mathbf{l})$ & $\begin{array}{l}\text { Ethanol yields } \mathbf{\%} \text { of the theoretical } \\
\text { yield) }\end{array}$ & $\begin{array}{l}\text { Ethanol } \\
\text { productivity } \\
(\mathbf{g} / \mathbf{l} / \mathbf{h})\end{array}$ \\
\hline 100 & 16 & $38.1 \pm 1.1$ & $74.6 \pm 2.2$ & $2.4 \pm 0.1$ \\
& 40 & $34.9 \pm 2.2$ & $68.3 \pm 4.3$ & $0.9 \pm 0.1$ \\
& 72 & $34.9 \pm 2.2$ & $68.3 \pm 4.3$ & $0.5 \pm 0.0$ \\
160 & 16 & $37.2 \pm 4.0$ & $45.5 \pm 4.9$ & $2.3 \pm 0.3$ \\
& 40 & $42.5 \pm 1.4$ & $52.0 \pm 1.7$ & $1.1 \pm 0.0$ \\
200 & 72 & $40.6 \pm 1.8$ & $49.6 \pm 2.2$ & $0.6 \pm 0.0$ \\
& 16 & $34.0 \pm 2.1$ & $33.2 \pm 2.1$ & $2.1 \pm 0.1$ \\
& 40 & $47.1 \pm 2.1$ & $46.0 \pm 2.1$ & $1.2 \pm 0.1$ \\
& 72 & $41.4 \pm 1.0$ & $40.5 \pm 1.0$ & $0.6 \pm 0.0$ \\
\hline
\end{tabular}

Data are presented as the mean $\pm S D$ of the results from three biological replicates
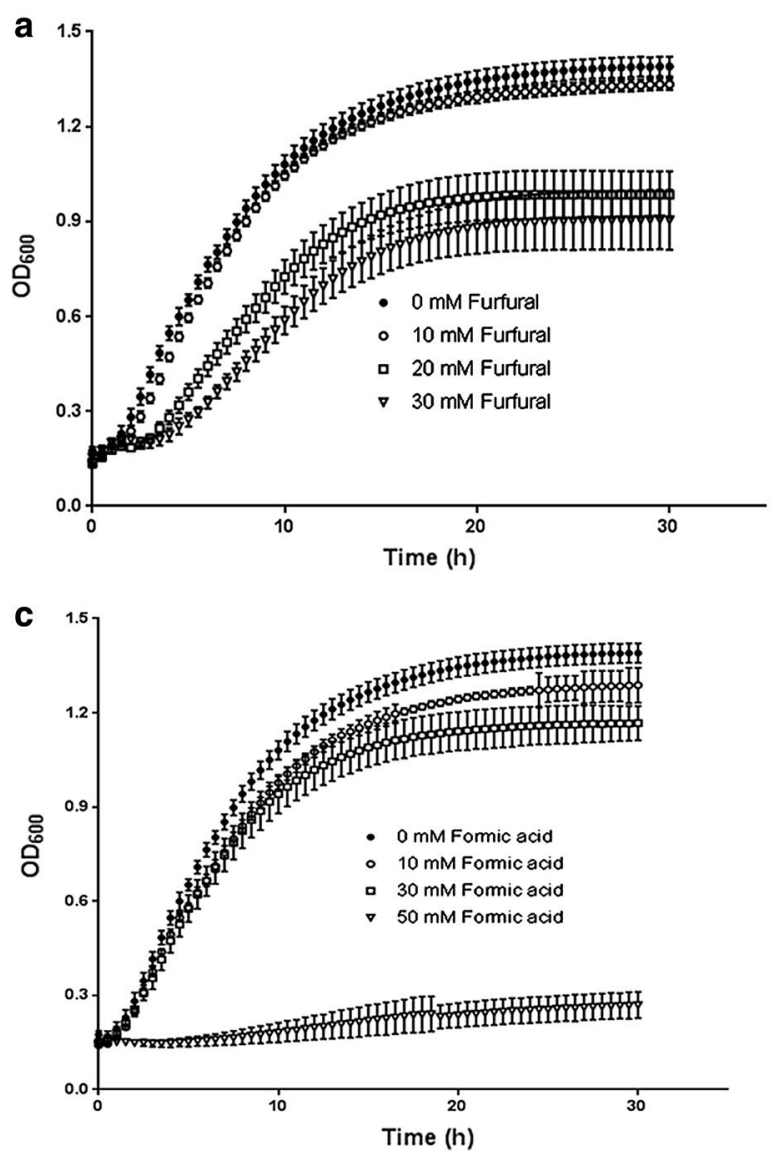

b

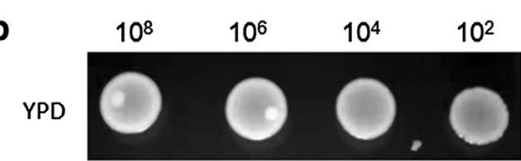

$10 \mathrm{mM}$

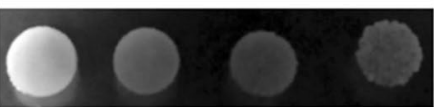

$20 \mathrm{mM}$

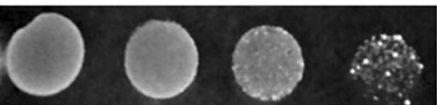

$30 \mathrm{mM}$

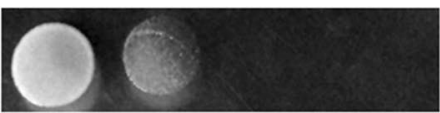

d

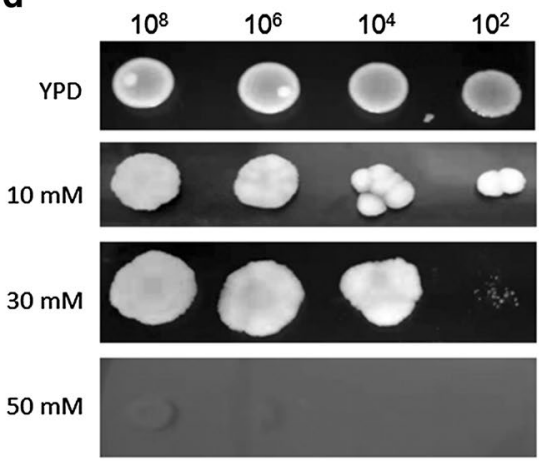

Fig. 2 Growth of P. kudriavzevii LC375240 in the presence of furfural and formic acid. a Kinetic growth curves of LC375240 in YPD broth supplemented with various concentrations of furfural were monitored using plate reader every $0.5 \mathrm{~h}$ interval for $30 \mathrm{~h}$ at $42^{\circ} \mathrm{C}$. $\mathbf{b}$ The indicated cell numbers were inoculated on YPD plates supplemented with various concentrations of furfural and incubated at $42^{\circ} \mathrm{C}$ for $48 \mathrm{~h}$. c Kinetic growth curves of LC375240 in YPD broth supplemented with various concentrations of formic acid were monitored using plate reader every $0.5 \mathrm{~h}$ interval for $30 \mathrm{~h}$ at $42^{\circ} \mathrm{C}$. $\mathbf{d}$ The indicated cell numbers were inoculated on YPD plates supplemented with various concentrations of formic acid and incubated at $42^{\circ} \mathrm{C}$ for $48 \mathrm{~h}$ 
resistant to the other two agents, we tested its growth in the presence of furfural and formic acid at $42{ }^{\circ} \mathrm{C}$. As shown in Fig. 2a, the growth of LC375240 in the presence of $10 \mathrm{mM}$ furfural was nearly the same as in YPD medium. However, the growth slightly decreased in the presence of $20 \mathrm{mM}$ and $30 \mathrm{mM}$ furfural. Consistently, the same inhibition trend was seen on YPD plates with furfural supplementation (Fig. 2b).

The effect of formic acid on the growth of LC375240 was also tested. Interestingly, the LC375240 grew well in the presence of $10 \mathrm{mM}$ and $30 \mathrm{mM}$ formic acid both in liquid cultivation and on YPD plates (Fig. 2c, d). However, in a medium with $50 \mathrm{mM}$ formic acid the growth of LC375240 was severely repressed. Taken together, P. kudriavzevii LC375240 exhibits stress tolerance against furfural and formic acid.

\section{Ethanol production by P. kudriavzevii LC375240} in the presence of furfural, acetic acid and formic acid The effects of furfural, acetic acid and formic acid on ethanol production were evaluated at $42{ }^{\circ} \mathrm{C}$ fermentation, and kinetic parameters that were calculated are listed in Table 2. In the presence of $10 \mathrm{mM}$ and $20 \mathrm{mM}$ furfural relatively high ethanol concentration, ethanol yield and ethanol productivity were obtained, although ethanol production was significantly reduced in $30 \mathrm{mM}$ furfural (Table 2). Our P. kudriavzevii LC375240 strain maintained high ethanol production even in the presence of $70 \mathrm{mM}$ acetic acid with yield of $63 \%$ at $40 \mathrm{~h}$ and

Table 2 Kinetic parameters of ethanol production from $100 \mathrm{~g} / \mathrm{l} \mathrm{glucose}$ in the presence of inhibitory substances at $42{ }^{\circ} \mathrm{C}$

\begin{tabular}{|c|c|c|c|c|}
\hline Inhibitors [29] & Time (h) & Ethanol concentration ( $g / l)$ & $\begin{array}{l}\text { Ethanol yields (\% of the theoretical } \\
\text { yield) }\end{array}$ & $\begin{array}{l}\text { Ethanol } \\
\text { productivity } \\
\text { (g/l/h) }\end{array}$ \\
\hline \multicolumn{5}{|l|}{ Furfural } \\
\hline \multirow[t]{3}{*}{10} & 16 & $29.0 \pm 1.6$ & $56.8 \pm 3.1$ & $1.8 \pm 0.1$ \\
\hline & 40 & $37.5 \pm 4.3$ & $73.4 \pm 8.4$ & $0.9 \pm 0.1$ \\
\hline & 72 & $36.3 \pm 3.8$ & $71.0 \pm 7.4$ & $0.5 \pm 0.1$ \\
\hline \multirow[t]{3}{*}{20} & 16 & $29.0 \pm 1.2$ & $56.8 \pm 2.3$ & $1.8 \pm 0.1$ \\
\hline & 40 & $35.6 \pm 0.8$ & $69.7 \pm 1.6$ & $0.9 \pm 0.0$ \\
\hline & 72 & $31.7 \pm 1.3$ & $62.0 \pm 2.5$ & $0.4 \pm 0.0$ \\
\hline \multirow[t]{3}{*}{30} & 16 & $17.8 \pm 2.0$ & $34.8 \pm 3.9$ & $1.1 \pm 0.1$ \\
\hline & 40 & $26.8 \pm 2.9$ & $52.4 \pm 5.7$ & $0.7 \pm 0.1$ \\
\hline & 72 & $28.1 \pm 1.0$ & $55.0 \pm 2.0$ & $0.4 \pm 0.0$ \\
\hline \multicolumn{5}{|l|}{ Acetic acid } \\
\hline \multirow[t]{3}{*}{40} & 16 & $28.4 \pm 0.9$ & $55.6 \pm 1.8$ & $1.8 \pm 0.1$ \\
\hline & 40 & $41.2 \pm 0.8$ & $80.6 \pm 1.6$ & $1.0 \pm 0.0$ \\
\hline & 72 & $37.8 \pm 4.7$ & $74.0 \pm 9.2$ & $0.5 \pm 0.1$ \\
\hline \multirow[t]{3}{*}{50} & 16 & $27.3 \pm 1.7$ & $53.4 \pm 3.3$ & $1.7 \pm 0.1$ \\
\hline & 40 & $35.3 \pm 3.1$ & $69.1 \pm 6.1$ & $0.9 \pm 0.1$ \\
\hline & 72 & $39.9 \pm 1.1$ & $78.1 \pm 2.2$ & $0.6 \pm 0.0$ \\
\hline \multirow[t]{3}{*}{70} & 16 & $23.1 \pm 2.4$ & $45.2 \pm 4.7$ & $1.4 \pm 0.2$ \\
\hline & 40 & $32.4 \pm 1.7$ & $63.4 \pm 3.3$ & $0.8 \pm 0.0$ \\
\hline & 72 & $32.6 \pm 1.7$ & $63.8 \pm 3.3$ & $0.5 \pm 0.0$ \\
\hline \multicolumn{5}{|l|}{ Formic acid } \\
\hline \multirow[t]{3}{*}{25} & 16 & $36.1 \pm 1.2$ & $70.6 \pm 2.3$ & $2.3 \pm 0.1$ \\
\hline & 40 & $33.4 \pm 2.5$ & $65.4 \pm 4.9$ & $0.8 \pm 0.1$ \\
\hline & 72 & $32.8 \pm 3.9$ & $64.2 \pm 7.6$ & $0.5 \pm 0.1$ \\
\hline \multirow[t]{3}{*}{35} & 16 & $28.8 \pm 1.5$ & $56.4 \pm 2.9$ & $1.8 \pm 0.1$ \\
\hline & 40 & $34.2 \pm 1.0$ & $66.9 \pm 2.0$ & $0.9 \pm 0.0$ \\
\hline & 72 & $32.6 \pm 2.6$ & $63.8 \pm 5.1$ & $0.5 \pm 0.0$ \\
\hline \multirow[t]{3}{*}{45} & 16 & $20.3 \pm 1.1$ & $39.7 \pm 2.2$ & $1.3 \pm 0.1$ \\
\hline & 40 & $27.7 \pm 3.5$ & $54.2 \pm 6.8$ & $0.7 \pm 0.1$ \\
\hline & 72 & $32.0 \pm 1.8$ & $62.6 \pm 3.5$ & $0.4 \pm 0.0$ \\
\hline
\end{tabular}


$72 \mathrm{~h}$ (Table 2). Similarly, even in the presence of $45 \mathrm{mM}$ formic acid the ethanol concentration reached $32 \mathrm{~g} / \mathrm{l}$ at $72 \mathrm{~h}$, although the production was relatively lower at $16 \mathrm{~h}$ and $40 \mathrm{~h}$ compared to the amount in $25 \mathrm{mM}$ and $35 \mathrm{mM}$ formic acid. However, when mixed combinations such as $10 \mathrm{mM}$ furfural with $40 \mathrm{mM}$ acetic acid or $10 \mathrm{mM}$ furfural with $25 \mathrm{mM}$ formic acid were added, the LC372540 strain could not grow well at $42{ }^{\circ} \mathrm{C}$, therefore the ethanol production was too low to be detected. Nevertheless, our $P$. kudriavzevii LC375240 strain exhibited sound ethanol production at $42{ }^{\circ} \mathrm{C}$ in the presence of furfural, acetic acid and formic acid.

Tolerance of $P$. kudriavzevii LC375240 to hydrogen peroxide and ethanol

During industrial fermentation, oxidative stress is commonly induced as well as increased accumulation of bioethanol. Therefore we investigated the effects of hydrogen peroxide $\left(\mathrm{H}_{2} \mathrm{O}_{2}\right)$ and ethanol on the growth of P. kudriavzevii LC375240 at $42{ }^{\circ} \mathrm{C}$. As shown in Fig. 3a, the strain grew well in the presence of $10 \mathrm{mM}$ and $20 \mathrm{mM} \mathrm{H}_{2} \mathrm{O}_{2}$ in liquid culture, although the growth slightly dropped in the presence of $30 \mathrm{mM} \mathrm{H}_{2} \mathrm{O}_{2}$, demonstrating that $\mathrm{LC} 375240$ is tolerant to $\mathrm{H}_{2} \mathrm{O}_{2}$. This is also evident from the data in Fig. $3 \mathrm{~b}$ as the strain grew well on YPD plates supplemented with $\mathrm{H}_{2} \mathrm{O}_{2}$ up to $30 \mathrm{mM}$.

Although ethanol is the target product of bioethanol fermentation, it is also an inhibitory factor to the fermentation organisms particularly as the amount increases. However, our LC375240 strain displayed remarkable tolerance towards ethanol even at a concentration of $15 \%$ in both liquid culture (Fig. 3c) and on YPD plates (Fig. 3d). Obviously, strain LC375240 is highly tolerant to $\mathrm{H}_{2} \mathrm{O}_{2}$ and ethanol.
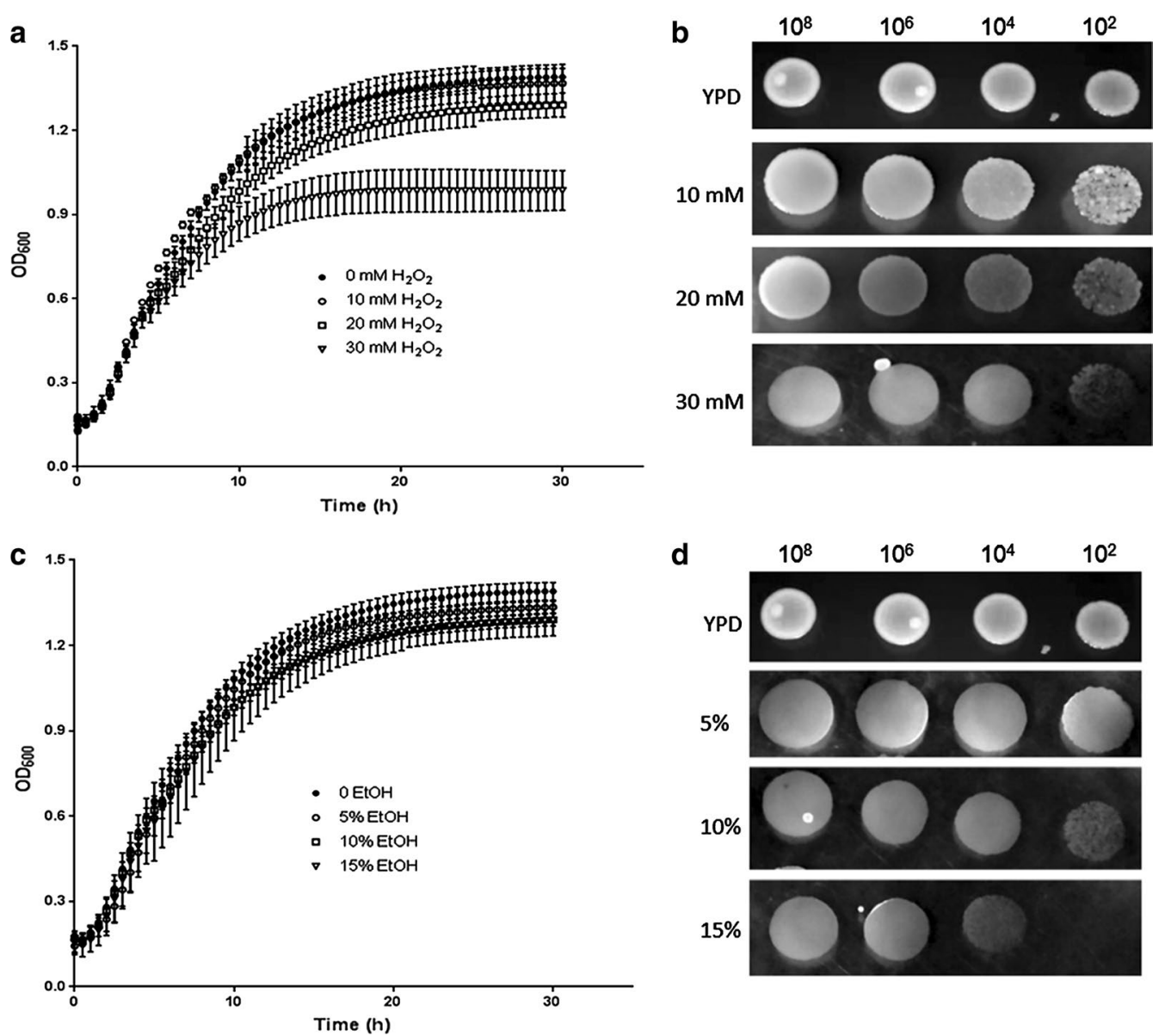

Fig. 3 Tolerance of P. kudriavzevii LC375240 to $\mathrm{H}_{2} \mathrm{O}_{2}$ and ethanol. a Kinetic growth curves of LC375240 in YPD broth supplemented with various concentrations of $\mathrm{H}_{2} \mathrm{O}_{2}$ were monitored using plate reader every $0.5 \mathrm{~h}$ interval for $30 \mathrm{~h}$ at $42^{\circ} \mathrm{C}$. $\mathbf{b}$ The indicated cell numbers were inoculated on YPD plates supplemented with various concentrations of $\mathrm{H}_{2} \mathrm{O}_{2}$ and incubated at $42^{\circ} \mathrm{C}$ for $48 \mathrm{~h}$. $\mathbf{c}$ Kinetic growth curves of LC 375240 in YPD broth supplemented with various percentages of ethanol were monitored using plate reader every $0.5 \mathrm{~h}$ interval for $30 \mathrm{~h}$ at $42^{\circ} \mathrm{C}$. $\mathbf{d}$ The indicated cell numbers were inoculated on YPD plates supplemented with various percentages of ethanol and incubated at $42^{\circ} \mathrm{C}$ for $48 \mathrm{~h}$ 


\section{Immobilization of $P$. kudriavzevii LC375240 on supporting materials}

Immobilization of yeast cells for ethanol production is a strategy used to protect cells from inhibitory compounds and stress conditions, to increase fermentation efficacy and to save cost in repeated batch fermentations. Calcium alginate beads are usually used to entrap the yeast cells. Here, we conducted immobilization of LC375240 not only in calcium alginate beads, but also on corncobs and coconut wastes, and we confirmed their immobilization efficacy using scanning electron microscopy (SEM). Surprisingly as shown by SEM in Fig. 4, very few P. kudriavzevii LC375240 cells were entrapped in the beads, relatively few cells were fixed on coconut wastes with clump and shrink morphology, whereas large amount of cells were efficiently attached to corncobs with wellstretched and separate morphology. It is reasonable to conclude that corncobs are the best supporting material for the immobilization of LC375240 cells when compared to coconut wastes and commonly used calcium alginate beads.

\section{Repeated batch fermentation using free cells and immobilized $P$. kudriavzevii LC375240}

To evaluate the effectiveness of the immobilized cells for ethanol production, repeated batch fermentations were conducted and compared to free cells. As shown in Table 3, cells immobilized on both corncobs and coconut wastes displayed $1.1 \mathrm{~g} / \mathrm{l} / \mathrm{h}$ of ethanol productivity which was significantly higher than the values obtained with free cells in the first and second batches of fermentation ( $p$ values are listed in Table 3 ). There was no significant statistical difference in ethanol productivity between corncobs immobilized cells and the free cells at the third and fourth batches of fermentation. Whereas compared to free cells, immobilized cells on coconut wastes showed no difference in third batch, there was a significantly reduced ethanol production for coconut waste, while corncobs and free cells remain stable at the fourth batch (Table 3). No statistical difference in ethanol production was observed between cells immobilized in calcium alginate beads and the free cells for the first, second and third batches, but significantly reduced ethanol production of beads-immobilized cells in the fourth batch of fermentation, which is probably due to bursting of the beads (Table 3). On the whole, free cells of P. kudriavzevii LC375240 were suitable for repeated batch fermentation, but immobilization on corncobs rendered more stable and higher efficient ethanol production throughout the repeated batch fermentation.

\section{Discussion}

Despite the increased worldwide attention on bioethanol production, the microorganisms for fermentation still encounter multiple challenges, particularly when using lignocellulosic hydrolysates as the feedstock during

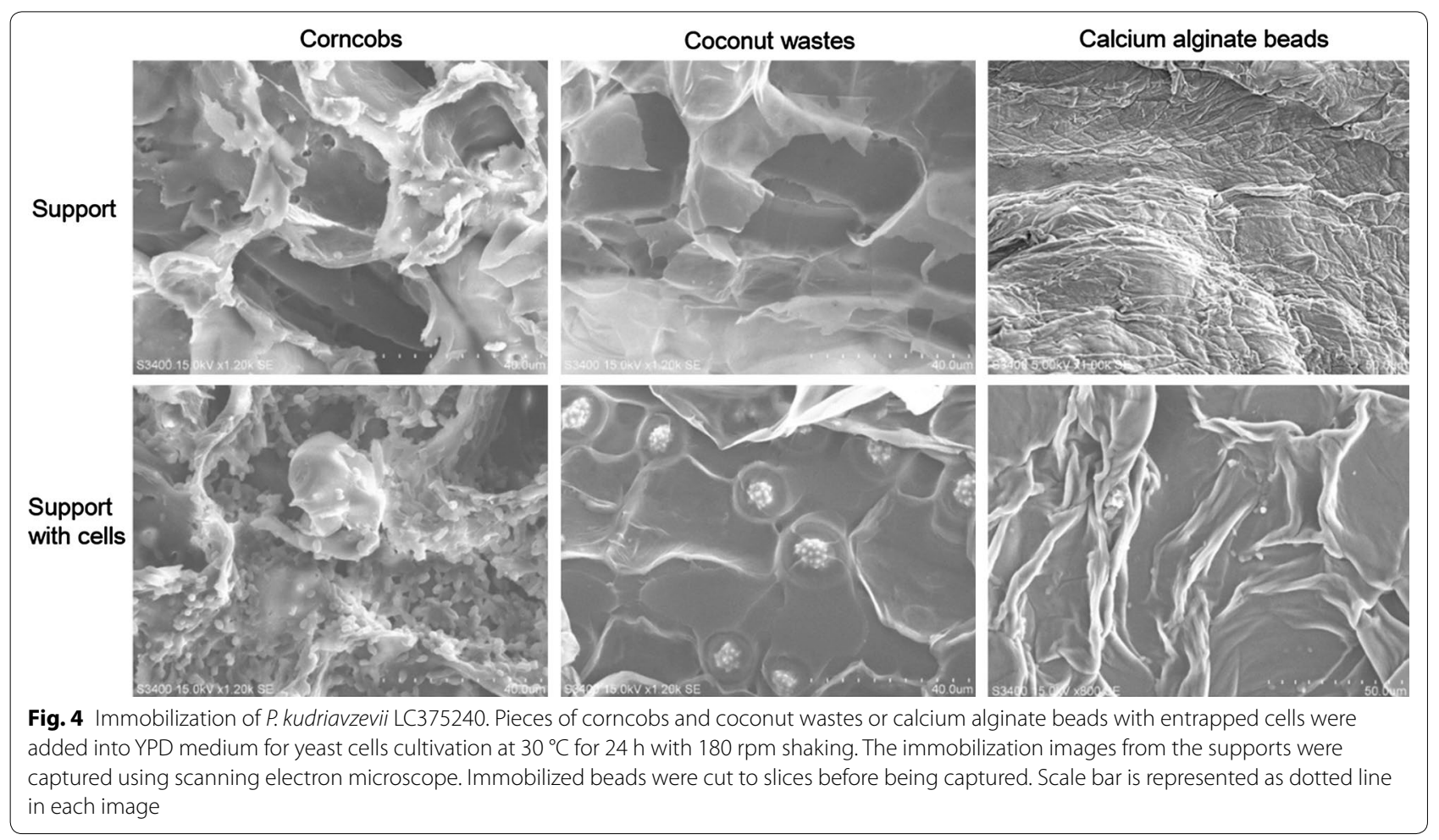


Table 3 Summary of bioethanol production from immobilized cells and free cells in repeated batch fermentation with $100 \mathrm{~g} / \mathrm{l}$ glucose at $42{ }^{\circ} \mathrm{C}$ for $40 \mathrm{~h}$ per batch

\begin{tabular}{|c|c|c|c|c|c|}
\hline Immobilization & Batch & Ethanol conc. (g/l) & $\begin{array}{l}\text { Ethanol yields (\% } \\
\text { of the theoretical yield) }\end{array}$ & $\begin{array}{l}\text { Ethanol } \\
\text { productivity (g/l/h) }\end{array}$ & Statistical $p$ values \\
\hline \multirow{4}{*}{ Free cells } & 1 & $36.9 \pm 2.4$ & $72.2 \pm 4.7$ & $0.9 \pm 0.1$ & - \\
\hline & 2 & $40.6 \pm 0.8$ & $79.5 \pm 1.6$ & $1.0 \pm 0.0$ & - \\
\hline & 3 & $42.1 \pm 1.7$ & $82.5 \pm 3.3$ & $1.1 \pm 0.0$ & - \\
\hline & 4 & $42.5 \pm 1.4$ & $83.1 \pm 2.7$ & $1.1 \pm 0.0$ & - \\
\hline \multirow[t]{4}{*}{ Corncobs } & 1 & $42.1 \pm 0.7$ & $82.4 \pm 1.4$ & $1.1 \pm 0.0$ & $0.0004^{* * *}$ \\
\hline & 2 & $42.3 \pm 1.1$ & $82.7 \pm 2.2$ & $1.1 \pm 0.0$ & $0.01^{*}$ \\
\hline & 3 & $42.6 \pm 2.2$ & $83.4 \pm 4.3$ & $1.1 \pm 0.1$ & $0.7, \mathrm{~ns}$ \\
\hline & 4 & $44.5 \pm 1.9$ & $87.1 \pm 3.7$ & $1.1 \pm 0.0$ & $0.06, \mathrm{~ns}$ \\
\hline \multirow[t]{4}{*}{ Coconut wastes } & 1 & $44.9 \pm 0.5$ & $87.9 \pm 1.0$ & $1.1 \pm 0.0$ & $0.00001^{* * *}$ \\
\hline & 2 & $44.4 \pm 2.2$ & $86.9 \pm 4.3$ & $1.1 \pm 0.1$ & $0.003^{* *}$ \\
\hline & 3 & $41.4 \pm 2.2$ & $81.0 \pm 4.3$ & $1.0 \pm 0.1$ & $0.5, \mathrm{~ns}$ \\
\hline & 4 & $36.0 \pm 2.6$ & $70.5 \pm 5.1$ & $0.9 \pm 0.1$ & $0.0004^{* * *}$ \\
\hline \multirow[t]{4}{*}{ Calcium alginate beads } & 1 & $38.3 \pm 1.2$ & $74.9 \pm 2.3$ & $1.0 \pm 0.0$ & $0.2, \mathrm{~ns}$ \\
\hline & 2 & $39.4 \pm 1.4$ & $77.0 \pm 2.7$ & $1.0 \pm 0.0$ & $0.08, \mathrm{~ns}$ \\
\hline & 3 & $42.2 \pm 2.0$ & $82.6 \pm 3.9$ & $1.1 \pm 0.1$ & $1.0, \mathrm{~ns}$ \\
\hline & 4 & $34.9 \pm 1.7$ & $68.3 \pm 3.3$ & $0.9 \pm 0.0$ & $0.000008^{* * *}$ \\
\hline
\end{tabular}

Data are presented as the mean \pm SD of the results from three biological replicates. One-way analysis of variance (ANOVA) was used to compare the ethanol production between the same batch of immobilized groups and the free cells group. Not significant $p>0.05$, ns; statistically significant $p \leq 0.05 *$; very significant $p \leq 0.01^{* *}$; highly significant $p \leq 0.001^{* * *}$

which multiple inhibitory substances are usually released. On top of these, thermotolerant yeast strains are required for SSF to reduce cost and avoid contamination. Several strategies such as over-liming of acid-treated biomass, adaptation of the fermentation microorganisms in the presence of toxic compounds and genetic engineering of microorganisms to improve resistance to inhibitory factors have been performed [3, 30]. However, these methods are time consuming and not very efficient. In a previous study, we isolated a thermotolerant $P$. kudriavzevii LC375240 from spoilt fruit, which exhibited tolerance to acetic acid up to $70 \mathrm{mM}$ [27]. Here, we confirmed the thermotolerant feature of this strain by studying its growth kinetics in liquid medium as well as growth on solid plates (Fig. 1a, b). The present study has shown that high glucose concentrations reduced ethanol yields at $42{ }^{\circ} \mathrm{C}$, probably due to the limited efficiency of converting glucose to ethanol (Fig. 1c). Interestingly, $P$. kudriavzevii LC375240 exhibited appreciable growth and ethanol production as well as tolerance to furfural, formic acid, $\mathrm{H}_{2} \mathrm{O}_{2}$ and ethanol at $42{ }^{\circ} \mathrm{C}$ (Figs. 2, 3 and Table 2). Several publications have reported that some P. kudriavzevii strains possess multi-stress tolerance [19, 30, 31]. These include P. kudriavzevii N77-4 which could tolerate $100 \mathrm{mM}$ acetic acid, but was sensitive to $6 \%$ ethanol at $30{ }^{\circ} \mathrm{C}$ [31]; P. kudriavzevii RZ8-1 that could grow on medium containing $5 \mathrm{~g} / \mathrm{l}$ acetic acid (approximately $82.5 \mathrm{mM}$ ) or higher than $12 \%$ ethanol at $35^{\circ} \mathrm{C}$ [19], and soil-isolated P. kudriavzevii that could grow at $12 \%$ ethanol, $1.44 \mathrm{~g} / \mathrm{l}$ (approximately $15 \mathrm{mM}$ ) furfural and $2.5 \mathrm{~g} / \mathrm{l}$ (approximately $41 \mathrm{mM}$ ) acetic acid [32]. Compared to these reported strains, P. kudriavzevii LC375240 clearly showed the highest tolerance to the inhibitory substances at $42{ }^{\circ} \mathrm{C}$, demonstrating that $P$. kudriavzevii LC375240 is a better thermotolerant and multi-stress-tolerant strain for bioethanol production.

Heat-shock proteins usually account for thermotolerance, whereas alcohol dehydrogenase is associated with ethanol production. In a previous study, it was reported that genes encoding heat-shock proteins such as ssq1 and $h s p 90$, and alcohol dehydrogenases such as adh1, adh2, adh3, adh4 as well as glyceraldehyde-3-phosphate dehydrogenase $t d h 2$ were up-regulated in a thermotolerant ethanol-producing P. kudriavzevii [19]. Genes such as $y d e P$, $y h i E$ or $y d e O$ were validated as acid resistance genes in $E$. coli since their deletion resulted in the elimination of resistance properties, whereas their overexpression conferred resistance to exponentially growing cells [33]. In addition, increased expression of either $R C N 1$ or $R S A 3$ genes improved the tolerance of wine yeast strains to ethanol, heat, osmotic and oxidative stresses [34]. It is therefore, necessary to investigate the expression level of those reported genes in our thermotolerant and multi-stress-tolerant $P$. kudriavzevii LC375240 strain in the future. Moreover, combination of genomic sequencing and transcriptomic analysis will probably reveal the 
novel genes that render multi-stress-tolerant feature to LC375240.

Utilization of pentose to produce bioethanol is important for the efficient conversion of lignocellulose biomass since some cellulosic hydrolysates consist of nearly $30-40 \%$ pentose such as xylose [35]. Our P. kudriavzevii LC375240 strain could use xylose and arabinose for growth, but at a slower rate than using glucose, and this is indicating the slower utilization efficiency of pentose (Fig. 1d). Higher concentration of xylose repressed growth, implying substrate inhibition towards xylose metabolic pathway. Genetic engineering of efficient pentose transport system, driving pentose to pentose phosphate pathway or natural selection of efficient pentose utilization strain are suggested approaches to improve the pentose utilization of LC375240 for ethanol production [35].

Immobilization of yeast cells on matrix such as $\mathrm{Ca}$ alginate beads offers the advantages of easy operation, reduced cost and protecting the cells from multiple stress conditions [8]. However, due to the low mass transfer efficiency and low stability, the beads-immobilized cells cannot be used over several batches. Instead immobilization of cells on lignocellulosic materials is easy, stable, reusable and cheap. Here, we compared immobilization of P. kudriavzevii LC375240 in Ca-alginate beads and lignocellulosic wastes (corncobs and coconut wastes). The immobilization efficiency and morphology of $P$. kudriavzevii cells on the three supporting materials were different. Immobilization on corncobs was the most efficient in terms of immobilized cell concentration and normal cell shape, whereas the alginate beads took in the least cells with shrink size (Fig. 4). Moreover, corncob-immobilized cells displayed consistent $1.1 \mathrm{~g} / \mathrm{l} / \mathrm{h}$ ethanol productivity during the four repeated batch fermentations. The stability and high ethanol production was better than free cells and cells immobilized by beads or coconut wastes.

Although there are not many reports on the immobilization of $P$. kudriavzevii for direct comparison, Zichova' et al. reported that ethanol production by poly(vinyl alcohol) hydrogel-entrapped $P$. kudriavzevii was higher than that produced by the free cells at $40{ }^{\circ} \mathrm{C}$ [14]. They also reported that the free cells of $P$. kudriavzevii lost viability after $90 \mathrm{~h}$ of fermentation at $40{ }^{\circ} \mathrm{C}$. In contrast, high ethanol production of $P$. kudriavzevii LC375240 was observed after four cycles of fermentation at $42{ }^{\circ} \mathrm{C}$ in this study. Laopaiboon and Laopaiboon (2012) reported that corncob-immobilized S. cerevisiae TISTR 5048 gave significantly higher ethanol concentration, yield and productivity than those immobilized on calcium alginate beads in repeated batch ethanol production [36]. Singh et al. reported that ethanol production from sugarcane bagasse-immobilized S. cerevisiae was higher than cells immobilized on Ca-alginate matrices [6]. The work also reported that $S$. cerevisiae immobilized on sugarcane bagasse could last up to 10 cycles in a repeated batch fermentation while the same cells immobilized in $\mathrm{Ca}$ alginate matrix lasted only 4 cycles. Ethanol production by Candida shehatae ATCC 22984 immobilized on terracotta beads, coconut bract and corncobs gave an average ethanol concentration of $17.03 \mathrm{~g} / \mathrm{l}, 17.20 \mathrm{~g} / \mathrm{l}$ and $16.40 \mathrm{~g} / \mathrm{l}$, respectively, after 5 cycles of fermentation while free cells had an average of $16.78 \mathrm{~g} / \mathrm{l}$ under the same condition [37]. These reports are in line with our finding that ethanol production is improved by immobilization, particularly on lignocellulosic materials such as corncobs with higher stability, durability and reusability when compared to entrapment in Ca-alginate matrix.

\section{Conclusion}

Being a thermotolerant strain for bioethanol production P. kudriavzevii LC375240 grew well at $42{ }^{\circ} \mathrm{C}$ at which conversional yeasts usually cannot survive. It produced high amount of ethanol from glucose, but could not utilize pentose such as xylose and arabinose to produce ethanol. It also exhibits strong tolerance to stresses such as acetic acid, furfural, formic acid, $\mathrm{H}_{2} \mathrm{O}_{2}$ and ethanol at $42{ }^{\circ} \mathrm{C}$. This multi-stress tolerance feature is unique to $P$. kudriavzevii LC375240 and makes it a good candidate strain for industrial application. Investigating the underlying tolerance mechanisms and using genetic manipulations to transfer the stress tolerance feature or genes to existing industrial strains are of particular interest for building stress-tolerant cell factories. In addition, simple immobilization of $P$. kudriavzevii LC375240 on corncobs led to stable production of ethanol in repeated batch fermentation, indicating that immobilization is another cheap option for high ethanol productivity.

\section{Materials and method \\ Strain}

Pichia kudriavzevii LC375240 used in this study was isolated from a spoilt fruit in Nigeria. The isolation, screening and identification procedure have been reported in a previous publication [27].

\section{Growth characterization of $P$. kudriavzevii LC375240 under different stress conditions}

Growth of $P$. kudriavzevii LC375240 under different stress conditions (temperature, ethanol, formic acid, furfural and $\mathrm{H}_{2} \mathrm{O}_{2}$ ) was determined in both liquid medium and on solid agar plates. A single yeast colony was inoculated into YPD medium (10 g/l yeast extract, $20 \mathrm{~g} / \mathrm{l}$ peptone, $20 \mathrm{~g} / \mathrm{l}$ glucose) and incubated at $37^{\circ} \mathrm{C}$ on a rotary incubator shaker at $200 \mathrm{rpm}$. After overnight incubation, the cells were harvested by centrifugation at $12,000 \mathrm{rpm}$ 
for $3 \mathrm{~min}$, and then washed with distilled water. They were diluted to optical density at $600 \mathrm{~nm}\left(\mathrm{OD}_{600}\right)$ of 0.1 in a 96-well plate and read by INFINITE 200PRO plate reader every $0.5 \mathrm{~h}$ at the setting conditions. For temperature stress, the plate was incubated at $30{ }^{\circ} \mathrm{C}, 37^{\circ} \mathrm{C}$ or $42{ }^{\circ} \mathrm{C}$ for $20 \mathrm{~h}$. For other stress conditions, the YPD medium was supplemented with different concentrations of the inhibitory compounds; furfural $(10 \mathrm{mM}, 20 \mathrm{mM}$ and $30 \mathrm{mM})$, formic acid $(10 \mathrm{mM}, 30 \mathrm{mM}$ and $50 \mathrm{mM})$, ethanol $(5 \%, 10 \%$ and $15 \%)$ and $\mathrm{H}_{2} \mathrm{O}_{2}(10 \mathrm{mM}, 20 \mathrm{mM}$ and $30 \mathrm{mM}$ ), and incubated at $42{ }^{\circ} \mathrm{C}$. The optical densities were measured every $0.5 \mathrm{~h}$ at $600 \mathrm{~nm}$ over a period of $30 \mathrm{~h}$ or longer. The sensitivity of the cells to these stresses during cultivation on agar plates was also investigated. In this case, overnight culture was centrifuged, washed with distilled water and then reconstituted with sterile distilled water. The cells were counted using haemocytometer. It was serially diluted from $2 \times 10^{8}$ cells $/ \mathrm{ml}$ to $2 \times 10^{2}$ cells $/ \mathrm{ml}$ and 5 - $\mu \mathrm{l}$ aliquots of $10^{8}, 10^{6}, 10^{4}$ and $10^{2}$ dilutions were spotted on YPD agar plates supplemented with various concentrations of the above inhibitors. To test growth on pentose sugars, xylose and arabinose were used to replace glucose in YPD to make plates, and the above inoculum was applied. The plates were incubated at $42{ }^{\circ} \mathrm{C}$ for $48 \mathrm{~h}$ and then used for photo-imaging.

\section{Effect of carbon source concentration on ethanol production}

The effect of carbon source concentration on ethanol production was investigated in YPD liquid medium with $100 \mathrm{~g} / \mathrm{l}, 160 \mathrm{~g} / \mathrm{l}$ and $200 \mathrm{~g} / \mathrm{l}$ glucose. Fermentations were performed at $42{ }^{\circ} \mathrm{C}$ on a rotary shaker at $200 \mathrm{rpm}$. Samples were withdrawn at $16 \mathrm{~h}, 40 \mathrm{~h}$ and $72 \mathrm{~h}$ to determine the ethanol concentration.

\section{Immobilization of $P$. kudriavzevii LC375240}

Three immobilization support materials (corncobs, coconut wastes and calcium alginate beads) were used for immobilization. For immobilization in calcium alginate beads $2 \%$ sodium alginate and $2 \%$ calcium chloride dihydrate were autoclaved at $121{ }^{\circ} \mathrm{C}$ for $15 \mathrm{~min}$ and allowed to cool. $2 \times 10^{8}$ of the yeast cells were mixed with $20 \mathrm{ml}$ of the sodium alginate solution. The sodium alginate solution containing the yeast cells was gradually dropped into $80 \mathrm{ml}$ of ice-cold $\mathrm{CaCl}_{2}$ solution using a dropper. The beads were allowed to harden at $4{ }^{\circ} \mathrm{C}$ for $24 \mathrm{~h}$. Then the beads were washed with sterile water and stored in sterile water at $4{ }^{\circ} \mathrm{C}$. A total of about 40 beads were produced and each bead contained about $5 \times 10^{6}$ cells.

For immobilization on other support materials the corncobs and coconut wastes were cut to a size of approximately $1 \mathrm{~cm} \times 2 \mathrm{~cm}$. They were washed and dried overnight at $70{ }^{\circ} \mathrm{C}$. The dried supports were autoclaved at
$121{ }^{\circ} \mathrm{C}$ for 20 min and allowed to cool. 15 pieces of each support were added to $70 \mathrm{ml}$ of YPD medium in a 250$\mathrm{ml}$ conical flask. The flasks were inoculated with $0.5 \mathrm{ml}$ of yeast cell suspension containing a total of $2 \times 10^{8}$ cells and incubated at $30^{\circ} \mathrm{C}$ and $180 \mathrm{rpm}$ for $24 \mathrm{~h}$ before use.

The images of the support materials with or without yeast cells were captured using scanning electron microscope. For the beads, they were cut before capturing the images.

\section{Repeated batch fermentation using immobilized and free yeast cells}

Normalization of the inoculum of the fermentation was based on the initial cell concentration before incubation. For cells immobilized in calcium alginate beads, 15 beads were added per flask giving an initial cell concentration of $7.5 \times 10^{7}$ per flask. In the case of the cells immobilized on corncobs and coconut fibers, three pieces of the fiber/ corncobs were used. If all the cells got attached the initial cell concentration was $4 \times 10^{7}$ cells per flask. However, the immobilization efficiency was not $100 \%$ and during the $24 \mathrm{~h}$ of immobilization procedure the attached cells also grew, so the actual cell concentration was more than $4 \times 10^{7}$ cells per flask. Free cells of $7.5 \times 10^{7}$ and the above inoculum from the support materials were inoculated into the 250-ml Erlenmeyer flask containing $100 \mathrm{ml}$ of $10 \%$ YPD. Cultures were incubated in a shaking incubator at $42{ }^{\circ} \mathrm{C}$ and $200 \mathrm{rpm}$ for $40 \mathrm{~h}$ per cycle. At the end of each fermentation run, the supports were collected from fermentation broth and washed with sterile distilled water then transferred to fresh media for subsequent batch fermentation. Free cells after each batch fermentation were centrifuged, $90 \%$ of the supernatant was discarded and replaced with fresh broth. Samples were taken at the end of each batch and analyzed for ethanol concentration.

\section{Ethanol determination and data analysis}

Ethanol concentration was analyzed by a gas chromatograph (GC-7890A, Agilent Technologies, USA) with a flame ionization detector using a glass column packed with FID $\left(\mathrm{N}_{2}\right.$ gas flow rate $=30 \mathrm{ml} / \mathrm{min}, \mathrm{H}_{2}=30 \mathrm{ml} /$ min, air $=300 \mathrm{ml} / \mathrm{min}$, injector $150{ }^{\circ} \mathrm{C}$, column $100{ }^{\circ} \mathrm{C}$, detector $250{ }^{\circ} \mathrm{C}$ ). Calculation of ethanol concentration was based on the equation showing linear relationship between ethanol peak area and acetonitrile peak area. The theoretical ethanol yields using $100 \mathrm{~g} / \mathrm{l}, 160 \mathrm{~g} / \mathrm{l}$ and $200 \mathrm{~g} / \mathrm{l}$ glucose are $51.1 \mathrm{~g} / \mathrm{l}, 81.8 \mathrm{~g} / \mathrm{l}$ and $102.3 \mathrm{~g} / \mathrm{l}$, respectively. The ethanol yield was calculated as the percentage ratio of actual ethanol yield to the theoretical ethanol yield. Ethanol productivity was calculated as the ratio of ethanol concentration $(\mathrm{g} / \mathrm{l})$ to the fermentation time (h). All fermentation experiments were performed in 
triplicates and all the experimental numerical data were expressed as the mean $\pm \mathrm{SD}$. One-way ANOVA was used for statistical analysis, where $p>0.05$ showing not significant; $p \leq 0.05$ showing statistically significant; $p \leq 0.01$ showing very significant and $p \leq 0.001$ showing highly significant. The final figure was made by GraphPad Prism 7.0 .

\section{Abbreviations}

SSF: Simultaneous saccharification and fermentation; $\mathrm{H}_{2} \mathrm{O}_{2}$ : Hydrogen peroxide; SEM: Scanning electron microscopy.

\section{Acknowledgements}

This work was funded by National Natural Science Foundation of China (31960032), Guangxi Natural Science Foundation (2018GXNSFAA138012) and Research Start-up Funding of Guangxi Academy of Sciences (2017YJJ025) to W.F., Bagui Scholar Program Fund (2016A24) of Guangxi Zhuang Autonomous Region to C.J.

\section{Authors' contributions}

IAN, JCO and WF conceived the study; IAN, QQ, GL performed experiments; IAN, JCO and WF analyzed and interpreted the data and wrote the manuscript with input from all authors. All authors read and approved the final manuscript.

\section{Funding}

This work was funded by National Natural Science Foundation of China (31960032), Guangxi Natural Science Foundation (2018GXNSFAA138012) and Research Start-up Funding of Guangxi Academy of Sciences (2017YJJ025) to W.F., Bagui Scholar Program Fund (2016A24) of Guangxi Zhuang Autonomous Region to C.J.

\section{Availability of data and materials}

All data generated or analyzed during this study are included in this article.

Ethics approval and consent to participate

Not applicable—no human subjects involved in study.

\section{Consent for publication}

Not applicable — no human subjects involved in study.

\section{Competing interests}

The authors declare that they have no competing interests.

\begin{abstract}
Author details
${ }^{1}$ National Engineering Research Center for Non-Food Biorefinery, Guangxi Academy of Sciences, Nanning, China. ${ }^{2}$ College of Life Science and Technology, Guangxi University, Nanning, China. ${ }^{3}$ State Key Laboratory of Non-Food Biomass and Enzyme Technology, Guangxi Academy of Sciences, Nanning, China. ${ }^{4}$ Department of Microbiology, University of Nigeria, Nsukka, Nigeria.
\end{abstract}

Received: 27 February 2020 Accepted: 11 May 2020

Published online: 18 May 2020

\section{References}

1. Ogbonna JC, Mashima H, Tanaka H. Scale up of fuel ethanol production from sugar beet juice using loofa sponge immobilized bioreactor. Bioresour Technol. 2001;76:1-8.

2. Alvira P, Tomas-Pejo E, Ballesteros M, Negro MJ. Pretreatment technologies for an efficient bioethanol production process based on enzymatic hydrolysis: a review. Bioresour Technol. 2010;101:4851-61.

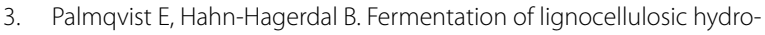
lysates II: inhibitors and mechanisms of inhibition. Bioresour Technol. 2000;74:25-33.
4. Caspeta L, Castillo T, Nielsen J. Modifying yeast tolerance to inhibitory conditions of ethanol production processes. Front Bioeng Biotechnol. 2015;3:184.

5. Bazso-Dombi E, Oravecz K, Jeney F, Nagy K, Zs-Nagy I. On the useful role of $\mathrm{OH}$ center dot free radicals in differentiation of cultured human fibroblasts. Arch Gerontol Geriatr. 2000;31:233-42.

6. Singh A, Sharma P, Saran AK, Singh N, Bishnoi NR. Comparative study on ethanol production from pretreated sugarcane bagasse using immobilized Saccharomyces cerevisiae on various matrices. Renew Energy. 2013;50:488-93.

7. Behera S, Mohanty RC, Ray RC. Ethanol production from mahula (Madhuca latifolia L.) flowers with immobilized cells of Saccharomyces cerevisiae in Luffa cylindrica L. sponge discs. Appl Energy. 2011;88:212-5.

8. Duarte JC, Rodrigues JAR, Moran PJS, Valenca GP, Nunhez JR. Effect of immobilized cells in calcium alginate beads in alcoholic fermentation. AMB Express. 2013;3:31.

9. Malhotra I, Basir SF. Immobilization of invertase in calcium alginate and calcium alginate-kappa-carrageenan beads and its application in bioethanol production. Prep Biochem Biotechnol. 2020;50(5):494-503. https://doi.org/10.1080/10826068.2019.1709979.

10. Uemura Y, Hamakawa N, Yoshizawa H, Ando H, ljichi K, Hatate Y. Effect of calcium alginate coating on the performance of immobilized yeast cells in calcium alginate beads. Chem Eng Commun. 2000;177:1-14.

11. Agudelo LM, Penuela M. Yeast immobilization on lignocellulosic materials for ethanol production used as fuel. J Biotechnol. 2010;150:S346-S346.

12. Chandel AK, Narasu ML, Chandrasekhar G, Manikyam A, Rao LV. Use of Saccharum spontaneum (wild sugarcane) as biomaterial for cell immobilization and modulated ethanol production by thermotolerant Saccharomyces cerevisiae VS3. Bioresour Technol. 2009;100:2404-10.

13. Ogbonna JC, Liu YC, Liu YK, Tanaka H. Loofa (Luffa cylindrica) sponge as a carrier for microbial cell immobilization. J Ferment Bioeng. 1994;78:437-42.

14. Zichova M, Stratilova E, Omelkova J, Vadkertiova R, Babak L, Rosenberg M. Production of ethanol from waste paper using immobilized yeasts. Chem Pap. 2017;71:553-61.

15. Lu J, Li XZ, Yang RF, Yang L, Zhao J, Liu YJ, Qu YB. Fed-batch semi-simultaneous saccharification and fermentation of reed pretreated with liquid hot water for bio-ethanol production using Saccharomyces cerevisiae. Bioresour Technol. 2013;144:539-47.

16. Ohta K, Hamada S, Nakamura T. Production of high-concentrations of ethanol from insulin by simultaneous saccharification and fermentation using Aspergillus niger and Saccharomyces cerevisiae. Appl Environ Microbiol. 1993;59:729-33.

17. Limtong S, Sringiew C, Yongmanitchai W. Production of fuel ethanol at high temperature from sugar cane juice by a newly isolated Kluyveromyces marxianus. Bioresour Technol. 2007;98:3367-74.

18. Nuanpeng S, Thanonkeo S, Yamada M, Thanonkeo P. Ethanol production from sweet sorghum juice at high temperatures using a newly isolated thermotolerant yeast Saccharomyces cerevisiae DBKKU Y-53. Energies. 2016;9:253.

19. Chamnipa N, Thanonkeo S, Klanrit P, Thanonkeo P. The potential of the newly isolated thermotolerant yeast Pichia kudriavzevii RZ8-1 for hightemperature ethanol production. Braz J Microbiol. 2018;49:378-91.

20. Nwuche CO, Murata Y, Nweze JE, Ndubuisi IA, Ohmae H, Saito M, Ogbonna JC. Bioethanol production under multiple stress condition by a new acid and temperature tolerant Saccharomyces cerevisiae strain LC 269108 isolated from rotten fruits. Process Biochem. 2018;67:105-12.

21. Mukherjee V, Radecka D, Aerts G, Verstrepen KJ, Lievens B, Thevelein JM Phenotypic landscape of non-conventional yeast species for different stress tolerance traits desirable in bioethanol fermentation. Biotechnol Biofuels. 2017;10:216.

22. Dhaliwal SS, Oberoi HS, Sandhu SK, Nanda D, Kumar D, Uppal SK. Enhanced ethanol production from sugarcane juice by galactose adaptation of a newly isolated thermotolerant strain of Pichia kudriavzevii. Bioresour Technol. 2011;102:5968-75.

23. Oberoi HS, Babbar N, Sandhu SK, Dhaliwal SS, Kaur U, Chadha BS, Bhargav VK. Ethanol production from alkali-treated rice straw via simultaneous saccharification and fermentation using newly isolated thermotolerant Pichia kudriavzevii HOP-1. J Ind Microbiol Biotechnol. 2012;39:557-66.

24. Yuangsaard $N$, Yongmanitchai $W$, Yamada M, Limtong S. Selection and characterization of a newly isolated thermotolerant Pichia kudriavzevii 
strain for ethanol production at high temperature from cassava starch hydrolysate. Antonie Van Leeuwenhoek Int J Gen Mol Microbiol. 2013;103:577-88

25. Isono N, Hayakawa H, Usami A, Mishima T, Hisamatsu M. A comparative study of ethanol production by Issatchenkia orientalis strains under stress conditions. J Biosci Bioeng. 2012;113:76-8.

26. Kwon YJ, Ma AZ, Li Q, Wang F, Zhuang GQ, Liu CZ. Effect of lignocellulosic inhibitory compounds on growth and ethanol fermentation of newly-isolated thermotolerant Issatchenkia orientalis. Bioresour Technol. 2011;102:8099-104

27. Ndubuisi IA, Nweze JE, Onoyima NJ, Yoshinori M, Ogbonna JC. Ethanol production from cassava pulp by a newly isolated thermotolerant Pichia kudriavzevii LC375240. Energy Power Eng. 2018;10:457-74.

28. Mohd Azhar SH, Abdulla R, Jambo SA, Marbawi H, Gansau JA, Mohd Faik AA, Rodrigues KF. Yeasts in sustainable bioethanol production: a review. Biochem Biophys Rep. 2017;10:52-61.

29. Schauwvlieghe A, Rijnders BJA, Philips N, Verwijs R, Vanderbeke L, Van Tienen C, Lagrou K, Verweij PE, Van de Veerdonk FL, Gommers D, et al. Invasive aspergillosis in patients admitted to the intensive care unit with severe influenza: a retrospective cohort study. Lancet Respir Med. 2018;6:782-92.

30. Jonsson $L$, Alriksson B, Nilvebrant NO. Bioconversion of lignocellulose: inhibitors and detoxification. Biotechnol Biofuels. 2013;6:16.

31. Sugiyama M, Baek SY, Takashima S, Miyashita N, Ishida K, Mun J, Yeo $\mathrm{SH}$. Overexpression of PkINO1 improves ethanol resistance of Pichia kudriavzevii N77-4 isolated from the Korean traditional fermentation starter nuruk. J Biosci Bioeng. 2018;126:682-9.

32. Ruyters S, Mukherjee V, Verstrepen KJ, Thevelein JM, Willems KA, Lievens B. Assessing the potential of wild yeasts for bioethanol production. J Ind Microbiol Biotechnol. 2015;42:39-48.

33. Masuda N, Church GM. Regulatory network of acid resistance genes in Escherichia coli. Mol Microbiol. 2003;48:699-712.

34. Anderson MJ, Barker SL, Boone C, Measday V. Identification of RCN1 and RSA3 as ethanol-tolerant genes in Saccharomyces cerevisiae using a high copy barcoded library. FEMS Yeast Res. 2012;12:48-60.

35. Hou J, Qiu C, Shen Y, Li H, Bao X. Engineering of Saccharomyces cerevisiae for the efficient co-utilization of glucose and xylose. FEMS Yeast Res. 2017;17(4):fox034. https://doi.org/10.1093/femsyr/fox034.

36. Laopaiboon L, Laopaiboon P. Ethanol production from sweet sorghum juice in repeated-batch fermentation by Saccharomyces cerevisiae immobilized on corncob. World J Microbiol Biotechnol. 2012;28:559-66.

37. Yuvadetkun P, Reungsang A, Boonmee M. Comparison between free cells and immobilized cells of Candida shehatae in ethanol production from rice straw hydrolysate using repeated batch cultivation. Renew Energy. 2018;115:634-40.

\section{Publisher's Note}

Springer Nature remains neutral with regard to jurisdictional claims in published maps and institutional affiliations.
Ready to submit your research? Choose BMC and benefit from:

- fast, convenient online submission

- thorough peer review by experienced researchers in your field

- rapid publication on acceptance

- support for research data, including large and complex data types

- gold Open Access which fosters wider collaboration and increased citations

- maximum visibility for your research: over 100M website views per year

At BMC, research is always in progress.

Learn more biomedcentral.com/submissions 